\title{
Serum Uric Acid Level in Primigravidae with Pre-Eclampsia: A Case Control Study from Karnataka
}

\author{
Veena H C $\mathbf{C}^{1}$, Manjunatha $\mathbf{S}^{2}$ \\ ${ }^{1}$ Assisstant Professor, Kodagu Institute of Medical Sciences, Madikeri, Karnataka, \\ ${ }^{2}$ Professor and HOD, Dept of OBG, Kodagu Institute of Medical Sciences, Madikeri, Karnataka
}

\begin{abstract}
Introduction: Pregnancy inducedhypertension is an exclusive condition affecting $10 \%$ ofpregnant women. The study of uric acid in serum is an interesting problemespecially in normal pregnancy and pregnancy inducedhypertension $(\mathrm{PIH})$. Objective: To compare the changes of serum uric acid level in healthy non pregnant, PIH and normotensive pregnant women. Methodology: Cross sectional observational study conducted in the Obstetrics and Gynecology department, hospital, Navodaya medical college , Raichur, Karnataka involving 30 each pregnant, PIH and non-pregnant women. Serum uric acid levels were measured and analysed the data using SPSS 23 version software. Results: Comparison ofmean serum uric acid level in pregnant normotensive $(4.14 \pm 1.05)$ and in $\mathrm{PIH}$ women $(6.03 \pm 1.61)$ was found significant. Comparison of mean serum uric acid level in pregnant normotensive women $(4.14 \pm 1.05)$ and in non pregnant women ( $3.39 \pm 0.5$ ) found significant. Mean serum uric acid level in PIH women was $6.03 \pm 1.61$ whereas in non pregnant women was $3.39 \pm 0.5(\mathrm{p}<0.001)$. Conclusion:Serum uric acid level is at higher side in PIH women as compared to pregnant normotensives and non pregnant women in our study.
\end{abstract}

Key words: Serum uric acid, PIH, preeclampsia, preganancy

\section{Introduction}

Quality of life of mother and newborn has become an important concern in todays era. Hypertensive disorders are amongst the most common medical disorders during pregnancy. It is also responsible for maternal and perinatal morbidity and mortality. ${ }^{1}$ In developing countries $7-10 \%$ of all pregnancies complicated by some form of hypertensive disorder and lead to various maternal and fetal complications. ${ }^{2}$ Pre-eclampsia and eclampsia is still reported as "a disease of theories" since its etiology is still obscured. The crux in the pathophysiology of preeclampsia appears to be endothelial cell dysfunction. ${ }^{3}$ Pre-eclampsia is a multisystem disorder characterized by hypertension to the extent of $140 / 90 \mathrm{~mm} \mathrm{Hg}$ or more, proteinuria ( $\geq 300 \mathrm{mg} /$ day) and edema induced by pregnancy after 20 th week. ${ }^{4} \mathrm{We}$ know that serial changes

\section{Corresponding Author:}

\section{Dr Anitha K,}

Associate Professor, Dept of Physiology, Navodaya

Medical College, Raichur, Karnataka.

Email ID dranithaks@gmail.com occur in serum uric acid level in normal pregnancy and pregnancy induced hypertension. ${ }^{5}{ }^{6}$ The raised levels of uric acid in the pregnancy induced hypertension were considered to be due to its diminished destruction in liver. Stander and Cadden ${ }^{7}$ did not find impairment of uric acid excretion, but, Seitchik ${ }^{8}$ showed that there was excessive reabsorption of urate by renal tubules in toxaemic conditions.Reduced uric acid clearance secondary to reduced glomerular filtration rate, increased reabsorption, and decreased secretion may be at the origin of elevated serum levels in women with preeclampsia., ${ }^{9,10}$

So, in view of the greater emphasis being placed on maternal and child health in present era, we want to revisit serum uric acid as a useful biomarker, which is extremely cheap \& widely available and early screening will definitely help in prevention of medical emergency.

\section{Objectives:}

- To compare the changes of serum uric acid level in healthy non pregnant women and healthy pregnant women 
- To compare the changes of serum uric acid level in healthy pregnant women and pre-eclampsia patients

- To compare the changes of serum uric acid level in healthy non pregnant women and pre-eclampsia patients

\section{Methodology}

Study population: The study was conducted in the Obstetrics and Gynecology department, Navodaya medical college, Raichur, Karnataka. Total 90 women volunteers were selected out of which 30 healthy nonpregnant women, 30 pregnant women and 30 pregnant women with preeclampsia were considered as subjects. 30 healthy non-pregnant women were considered as control. 30 normal pregnant and 30 pre-eclamptic women were taken from the outpatients and inpatients wards of Obstetrics and Gynecology department. Ethical Clearancewas taken fromInstitutionalEthical Committee.

Study duration: one year

Study design: Case control study

Inclusion criteria:

- Age $>18$ years, singleton pregnancy beyond the 20th week pregnancy was taken for the study

- 30 healthy pregnant women were considered for the study.

- 30 pregnant women with pre-eclampsia who fulfill above criteria was considered.

Exclusion Criteria: Patients with history of hyperuricemia, preexisting diabetes, hypertension, renal disease, thyrotoxicosis, liver disease, cardiovascular illness, and symptomatic infectious diseases were excluded.

The diagnosis of preeclampsia was based on the definition of American College of Obstetrics and Gynaecologists. ${ }^{14}$ The criteria is as stated below:

1. Systolic blood pressure greater than $140 \mathrm{~mm}$ $\mathrm{Hg}$ or a rise of at least $30 \mathrm{~mm} \mathrm{Hg}$, and/ or

2. Diastolic blood pressure greater than $90 \mathrm{~mm}$ $\mathrm{Hg}$ or a rise of at least $15 \mathrm{~mm} \mathrm{Hg}$ (manifested on two occasions at least 6 hours apart), and/ or

3. Proteinuria of $300 \mathrm{mg}$ or greater in 24 hours urine collection or protein concentration of $1 \mathrm{gm} / \mathrm{L}$ (on two occasions at least 6 hours apart).

30 normal, healthy non-pregnant female volunteers selected for control study. They were of comparable age, and physical activity. They were non-smoker, not taking tobacco and free from any other metabolic or organic disorders. We collected necessary information about subject in Performa.

Method of collection of data:Each subject taking part in the study was explained about the purpose of the study and procedure to be adopted in the study. Informed consent was taken from all the subjects. A detailed history followed by clinical examination was carried out for each one of the subject.

Procedure: The blood pressure of the participants were measured with a standard mercury sphygmomanometer. Three readings were taken at the interval of 10 minutes. Proteinuria analysis were performed using standard procedures.Blood samples of participants were taken from right or left cubital vein would be collected in plain tubes and serum levels of uric acid was measured.

Determination of uric acid was carried out by quantitative estimation on colorimetric method by enzymatic uricase method, which has many advantages like single reagent system, one step procedure, prevents protein precipitation. Highly sensitive and specific and the reagent was stable. It is a very speedy method and one can determine uric acid within 5minutes and very small amount of serum was required.

Statistical analysis: Data was entered in MS excel sheet and analysed by using SPSS 23.0 version. The quantitative data was expressed as mean and standard deviation. Comparison of mean between two groups was done by suing unpaired $t$ test. A $p$ value less than 0.05 was considered as significant whereas $p<0.001$ was considered as highly significant.

\section{Results}

Table 1 depicts distribution of study population according to age group. In our study we involved 30 women in each group. Commonly observed age group in our study was between 21 to 30 years in all three groups. 93.3\% pregnant women, $63.3 \% \mathrm{PIH}$ women and $60 \%$ non pregnant women belongs to this age group. 
Table 2 shows distribution according to mean age group of study population. Mean age of pregnant normotensive women was $25.53 \pm 3.16$ years. Mean age of PIH women was $24.33 \pm 4.70$ years. Mean age of nonpregnant women was $21.53 \pm 2.46$ years.

Table 3 explains about comparison of mean serum uric acid level in pregnant normotensive and PIH women. Mean serum uric acid level in pregnant normotensive women was $4.14 \pm 1.05$ whereas in $\mathrm{PIH}$ women was $6.03 \pm 1.61$. When we compared the uric acid levels in both groups, it was found to be statistically significant $(\mathrm{p}<0.001)$. It means serum uric acid level in PIH group was considerably higher as compared to pregnant normotensive women in our study.

Table 4 explains comparison of mean serum uric acid level in pregnant normotensive and non pregnant women. Mean serum uric acid level in pregnant normotensive women was $4.14 \pm 1.05$ whereas in non pregnant women was $3.39 \pm 0.5$. When we compared the uric acid levels in both groups, it was found to be statistically significant $(p<0.001)$. It means serum uric acid level in pregnant normotensive group was at higher side compared to non pregnant women in our study.

Table 5 shows comparison of mean serum uric acid level in PIH and non pregnant women. Mean serum uric acid level in PIH women was $6.03 \pm 1.61$ whereas in non pregnant women was $3.39 \pm 0.5$. When we compared the uric acid levels in both groups, it was found to be statistically significant $(\mathrm{p}<0.001)$. It means serum uric acid level in PIH group was at higher side compared to non pregnant women in our study.

Table 1: Distribution according to age group of study population

\begin{tabular}{|c|c|c|c|c|c|c|c|}
\hline \multirow{2}{*}{\multicolumn{2}{|c|}{ Frequency }} & \multicolumn{2}{|c|}{ Pregnant } & \multicolumn{2}{|l|}{ PIH } & \multicolumn{2}{|c|}{ Non pregnant } \\
\hline & & \multirow{2}{*}{$\begin{array}{l}\text { Percent } \\
1\end{array}$} & \multirow{2}{*}{$\begin{array}{l}\text { Frequency } \\
3.3\end{array}$} & \multirow{2}{*}{$\begin{array}{l}\text { Percent } \\
8\end{array}$} & \multirow{2}{*}{$\begin{array}{l}\text { Frequency } \\
26.7\end{array}$} & \multirow{2}{*}{$\frac{\text { Percent }}{12}$} & \multirow[b]{2}{*}{40.0} \\
\hline \multirow{4}{*}{$\begin{array}{l}\text { Age group } \\
\text { in years }\end{array}$} & $\leq 20$ & & & & & & \\
\hline & $21-30$ & 28 & 93.3 & 19 & 63.3 & 18 & 60.0 \\
\hline & $>30$ & 1 & 3.3 & 3 & 10.0 & 0 & 0 \\
\hline & Total & 30 & 100.0 & 30 & 100.0 & 30 & 100.0 \\
\hline
\end{tabular}

Table 2: Distribution according to mean age group of study population

\begin{tabular}{|l|l|l|}
\hline & Mean & Std. Deviation \\
\hline Pregnant & 25.53 & 3.16 \\
\hline PIH & 24.33 & 4.70 \\
\hline Non pregnant & 21.53 & 2.46 \\
\hline
\end{tabular}

Table 3: Comparison of mean serum uric acid level in pregnant normotensive and PIH women

\begin{tabular}{|l|l|l|l|l|l|l|l|}
\hline & Group & $\mathbf{N}$ & Mean & $\begin{array}{l}\text { Std. } \\
\text { Deviation }\end{array}$ & $\mathbf{t}$ & $\mathbf{p}$ & Inference \\
\hline \multirow{2}{*}{ Uric acid } & Pregnant & 30 & 4.14 & 1.05 & & 0.0001 & \multirow{2}{*}{$\begin{array}{l}\text { Highly } \\
\text { significant }\end{array}$} \\
\cline { 2 - 5 } & PIH & 30 & 6.03 & 1.61 & & $(<0.003)$ & \\
\hline
\end{tabular}


Table 4: Comparison of mean serum uric acid level in pregnant normotensive and non pregnant women

\begin{tabular}{|l|l|l|l|l|l|l|l|}
\hline & Group & $\mathbf{N}$ & Mean & $\begin{array}{l}\text { Std. } \\
\text { Deviation }\end{array}$ & $\mathbf{t}$ & $\mathbf{p}$ & Inference \\
\hline \multirow{3}{*}{ Uric acid } & Pregnant & 30 & 4.14 & 1.05 & \multirow{2}{*}{3.500} & 0.001 & $\begin{array}{l}\text { Highly } \\
\text { significant }\end{array}$ \\
\cline { 2 - 5 } & Non pregnant & 30 & 3.39 & .50 & & $(\leq 0.001)$ & \\
\hline
\end{tabular}

Table 5: Comparison of mean serum uric acid level in PIH and non pregnant women

\begin{tabular}{|c|c|c|c|c|c|c|c|}
\hline & Group & $\mathbf{N}$ & Mean & $\begin{array}{l}\text { Std. } \\
\text { Deviation }\end{array}$ & t & $\mathbf{p}$ & Inference \\
\hline \multirow{2}{*}{ Uric acid } & PIH & 30 & 6.03 & 1.61 & \multirow{2}{*}{8.571} & 0.0001 & \multirow{2}{*}{$\begin{array}{l}\text { Highly } \\
\text { significant }\end{array}$} \\
\hline & Non pregnant & 30 & 3.39 & .50 & & $(<0.001)$ & \\
\hline
\end{tabular}

\section{Discussion}

In our study we involved 30 women in each group. Commonly observed age group in our study was between 21 to 30 years in all three groups. $93.3 \%$ pregnant women, $63.3 \% \mathrm{PIH}$ women and $60 \%$ non-pregnant women belong to this age group. (table 1)

Mean age of pregnant normotensive women was $25.53 \pm 3.16$ years. Mean age of PIH women was $24.33 \pm$ 4.70 years. Mean age of non-pregnant women was $21.53 \pm 2.46$ years (table 2$)$.

Ajay kumar Singh et $\mathrm{a}^{11}$ conducted the study in Uttar Pradesh and reported the mean age $27.40 \pm 3.55$ years in Normotensives and $27.03 \pm 3.91$ years in PIH women in his study.

Mean serum uric acid level in pregnant normotensive women was $4.14 \pm 1.05$ whereas in PIH women was $6.03 \pm 1.61$. When we compared the uric acid levels in both groups, it was found to be statistically significant $(p<0.001)$. It means serum uric acid level in PIH group was considerably higher as compared to pregnant normotensive women in our study. (table 3)

Ajay kumar Singh et $\mathrm{a}^{11}$ found that mean serum uric acid level in normotensives was $4.94 \pm 0.83$ whereas in $\mathrm{PIH}$ it was $7.63 \pm 0.59$. The difference was significant.

Jasmin Diwan et al ${ }^{12}$ from Jamnagar, Gujrat reported that mean serum uric acid level was $4.6 \pm 0.42$ in normal pregnancy and it was $7.6 \pm 0.76$ in PIH women. They also found the difference between two groups serum uric acid significant.

Patel Tejal et al ${ }^{13}$ determined the mean serum uric acid level in the lasttrimester of pregnancy for the normal women to be $3.5 \pm 0.6 \mathrm{mg} \%$ and in preeclampsia group it was $6.4 \pm 1.7 \mathrm{mg} \%$.

Thereare couple of previous studies that highlights on the uric acid level in preeclampsia and its significant rise. ${ }^{14-16}$

Serum uric acid is one of the parameters used in earlydiagnosis of pregnancy induced hypertension. It was reported that there is positive correlation between hyperuricaemia and hypertension which distinguishes between pregnancyinduced hypertension and chronic hypertension.

Mean serum uric acid level in pregnant normotensive women was $4.14 \pm 1.05$ whereas in non- pregnant women was $3.39 \pm 0.5$. When we compared the uric acid levels in both groups, it was found to be statistically significant $(p<0.001)$. It means serum uric acid level in pregnant normotensive group was at higher side compared to nonpregnant women in our study. (table 4). Mean serum uric acid level in PIH women was $6.03 \pm 1.61$ whereas in non pregnant women was $3.39 \pm 0.5$. When we compared the uric acid levels in both groups, it was found to be statistically significant $(p<0.001)$. It means serum uric acid level in PIH group was at higher side compared to non pregnant women in our study. (table 5) 
Shah C J et.al ${ }^{17}$ stated that serum uric acid levels are significantly raised in pre eclampsia than normal pregnancy and there is a high positive correlation with the disease severity in relation to hypertension and proteinuria. Lim $\mathrm{KH}$ et $\mathrm{al}^{18}$ also stressed on the clinical utility of serum uric acid measurements in hypertensive diseases of pregnancy.

In non-pregnant women, hyperuricemia is anindependent predictor of cardiovascular and renaldisease in general population and in chronic hypertension.Elevated uric acid level in maternal blood, presumablydue to reduced renal urate excretion is frequently notedin preeclampsia.

\section{Conclusion}

Serum uric acid level is at higher side in PIH women as compared to pregnant normotensives and non pregnant women in our study. Present study show that uric acid isone of the important laboratory tests for screening of pre-eclampsia. The importance of continuousantenatal surveillance and thereof uric acid by laboratorytest in early identification of suspected and establishedcases of hypertension in pregnancy is thus evident. Thedisease can be identified early and its deterioration preventedby proper management.

\section{Conflict of Interest : Nil}

\section{Source of Funding : Self}

Ethical Clearance : Obtained from ethical clearance obtained from Human Ethical committee of Navodaya Medical College and Research center, Raichur.

\section{References}

1. Shah M R. Hypertensive disorders in pregnancy. 1st edn published by Jaypee. 2007:1-10.

2. Barrilleaux PS, Martin JN; Hypertensive therapy during pregnancy. ClinObstet Gynecol., 2002;45(1):22-34.

3. Cotter AM, Molloy AM, Scott JM, Daly SF. Elevated plasmahomocysteine in early pregnancy: a risk factor for the development of severe preeclampsia. American Journal of Obstetrics and Gynaecology.2001;185(4):781- 85.

4. Dutta D.C (2001), Hypertensive disorders in pregnancy, in :Textbook.

5. Lind T, Godfrey KA, Otun H. Changes in serum uricacid concentration during normal pregnancy.
Br Jr of obst and Gyne 1984; 91:128-132.

6. Mustaphi R, Gopalan S, Dhaliwal L, Sarkar AK. Hyperuricaemia and pregnancy induced hypertension-Reappraisal. Ind. J med Sci 1996(3);50:68-71

7. Stander HJ, Cadden JF. Blood chemistry in preeclampsia and eclampsia. Am. J of Obst. Gynecol 1934; 28:856-9.

8. Sietchik J. The metabolism of urate in preclampsia. Am. J of obst Gynecol 1956; 72:40-7.

9. Powers RW, Bodnar LM, Ness RB, Cooper KM, Gallaher MJ, Frank MP, Daftari AR, Roberts JM. Uric acid concentrations in early pregnancy among preeclamptic women with gestational hyperuricemia at delivery. Am J Obstet Gynecol. 2006;194:160:e1-e8.

10. Jeyabalan A, Conrad KP. Renal function during normal pregnancy andpreeclampsia. Front Biosci. 2007;12:2425-2437.

11. Singh AK, Kumar R, Singh VK, Srivastava S, Sharma A. Serum uric acid levels in pregnancy induced hypertension preeclampsia. Int $\mathrm{J}$ Clin Biochem Res. 2018;5(3):365-368

12. Jasmin Diwan, Chinmay Shah, Dixit, Anand AK. A Comparative Study of Serum Uric Acid Level in Normal Pregnancy, and Pregnancy Induced Hypertension. Int. J. Med. Public health 2011;1(1): $139-41$

13. Patel Tejal, Dudhat Astha. Relationship of Serum Uric Acid Level to Maternal and Perinatal Outcome in Patients with Hypertensive Disorders of Pregnancy. Gujarat medical journal 2014 ; 69(2):45-47

14. Hickman PE, Michael CA \& Potter JM, Serum uric acidas a marker of pregnancy-induced hypertension. Aust N ZJ Obstet Gynaecol. 1982;22:198-202.

15. Osakwe CR, Ikpeze OC, Ezebialu IU, Osakwe JO\& Mbadugha NN, The predictive value of serum uricacid for the occurrence, severity and outcomes of preeclampsiaamong parturients at nnewi Nigeria. Niger J Med. 2015;24(3):192-200.

16. Mazzali M, Hughes J, Kim YG, Jefferson JA, Kang DH, Gordon KL, Lan HY, Kivlighn S \& Johnson RJ, Elevated uric acid increases blood pressure in the rat by a novel crystal-independent mechanism. Hypertension. 2001;38(5)1101-1106.

17. Shah CJ.serum uric acid levels in PIH. Int. J.Med. 
Public health,2011;1(1):39-42

18. Lim KH, Friedman SA, Ecker JL, Kao L and. Kilpatrick SJ. The clinical utility of serum uric acid measurements in hypertensivediseases of pregnancy. Am J Obstet Gynecol. 1998 May;178(5):1067-71. 